\title{
Journal of Bacteriology and

\section{Bacterial Contamination of Hospital Surfaces According to Material Make, Last Time of Contact and Last Time of Cleaning/Disinfection}

\section{Saka KH, Akanbi II AA, Obasa TO, Raheem RA and Oshodi AJ}

Microbiology Unit, Nigerian Stored Products Research Institute, Kano, Nigeria

"Corresponding author: Saka Kayode Habeeb, Research Officer II, Microbiology Unit, Nigerian Stored Products Research Institute, Kano, Nigeria, Tel: +2348063090230; E-mail: saka.habeeb@yahoo.com

Received date: June 29, 2017; Accepted date: July 31, 2017; Published date: August 07, 2017

Copyright: ( 2017 Saka $\mathrm{KH}$, et al. This is an open-access article distributed under the terms of the creative commons attribution license, which permits unrestricted use, distribution, and reproduction in any medium, provided the original author and source are credited.

\begin{abstract}
Hospital cleaning and disinfection is the hallmark of infection control, over the past decade substantial scientific evidences has accumulated indicating that contamination of environmental surfaces in hospital rooms play an important role in the transmission of several key healthcare-associated pathogens.

A cross-sectional study of indoor surfaces at paediatric wards of the university of llorin Teaching hospital (UITH) was carried out to determine the pattern of bacterial contamination of surfaces according to material make of surfaces, last time of contact and last time of cleaning and disinfection. Eight common surfaces (bed rails, bed lockers, radiant warmers, incubators, trolleys, medical tables, door handle and wash sinks) which patients, patients relative and healthcare provider often interact with within daily cleaning that were made from different materials (Aluminium, ceramic, plastic and wood) was sampled.

The pattern of contaminants according to the material make show a statistical significance with $\mathrm{P}$-value=0.0044. $S$. aureus was the predominant contaminants on aluminium surfaces, Klebsiella pneumoniae and $A$. baumannii were found to be the major contaminant isolated from ceramic surfaces while $A$. baumannii was the predominant contaminant of wooden surfaces sampled. Pattern according to the last time of contact show a statistical significance with $\mathrm{P}$-value $=0.0043$. surfaces occupied by patient's was largely contaminated. Bacterial contamination pattern according to the time lapse of cleaning or disinfection: surfaces that had been cleaned for greater $4 \mathrm{~h}$ prior to sample collection were found to have been contaminated with $86.3 \%$ of the isolates. Surfaces that were cleaned or disinfected less than $2 \mathrm{~h}$ prior to sample collection remained largely uncontaminated. Enhanced cleaning, the use of no-touch methods for terminal room disinfection, and potentially the use of self-disinfecting surfaces may aid in reducing health care associated infections.
\end{abstract}

Keywords: Contamination; Surfaces; Cleaning; Disinfection; Paediatric; Healthcare-associated pathogens

\section{Introduction}

Environmental surfaces contamination provide a potential reservoir for pathogens to persist and cause infection in susceptible patients [1], environment were once thought to play a negligible role in the endemic transmission of pathogens [2,3]. Hospital environment is a reservoir of wide varieties of microorganisms, several strains of pathogenic bacteria have been frequently reported colonizing frequently touched sites [4] and surfaces near patients such as bed rails, tray tables, telephones, bedside tables, patient chairs, nurse call buttons, doorknobs, push plates, bed rails, faucet handles, and poles supporting intravenous fluid supplies are often heavily contaminated [5] and has been identified as reservoirs for the spread of pathogenic microbes $[1,6]$ it can easily contaminate hands and equipment of healthcare givers, who, in turn, can transmit these pathogens to patients during routine care [5].

For environmental contamination to play an important role in the acquisition of healthcare associated pathogen, the pathogen must demonstrate certain characteristic that will facilitate its transmission which include but not limited to their ability to survive for prolonged period of time on environmental surfaces, virulent after environmental exposure [7] and must have the ability to transiently colonize the hands of healthcare workers $[8,9]$. Different pathogen that persists on surfaces requires different condition to survive for a prolonged period of time. It was stated by Kramer et al. [10], that humid condition improves persistence of Chlamydia trachomatis, Listeria monocytogenes, Salmonella typhimurium, Pseudomonas aeruginosa and Escherichia coli. They reported that only Staphylococcus aureus was found to survive at low humidity. Low temperatures e.g. $4^{\circ} \mathrm{C}$ or $6^{\circ} \mathrm{C}$, also improve persistence of Listeria monocytogenes, Salmonella typhimurium, MRSA, Helicobacter pylori and Neisseria gonorrhea [8].

The surface environment in rooms of colonized or infected patients is frequently contaminated with pathogens that are capable of surviving on hospital room surfaces and medical equipment for a prolonged period of time. Contact with hospital room surfaces or medical equipment by healthcare personnel frequently leads to contamination of hands and/or gloves. The frequency with which room surfaces are contaminated correlates with the frequency of hand and/or glove contamination of healthcare personnel. Clonal outbreaks of pathogens contaminating the room surfaces of colonized or infected patients are demonstrated to be due to person-to-person transmission or shared medical equipment. The patient admitted to a room previously occupied by a patient colonized or infected with a pathogen (e.g. methicillin-resistant Staphylococcus aureus, vancomycin-resistant Enterococcus, Clostridium difficile, and Acinetobacter baumannii) has 
an increased likelihood of developing colonization or infection with that pathogen [11].

Cleaning is the removal of soil and contaminants from surfaces, whereas disinfection relates to the inactivation of pathogens by use of a disinfectant [12]. Disinfection is one of the cornerstones of infection prevention and control, defined as the antimicrobial reduction of micro-organisms to a level previously specified as appropriate [13]. Medical equipment used in the non-critical care setting is less likely to have standard disinfection and cleaning protocols than equipment in the critical care setting. Thus medical care equipment is more likely to carry considerable number of pathogenic microorganisms which is very important in cross contamination [4].

Microorganisms vary in their resistance to disinfectants, so agents must be chosen carefully for their effectiveness [14]. The presence of a pathogen on a surface does not necessarily represent a transmission risk. However, the infectious dose for most environmentally associated nosocomial pathogens appears to be low. For example, less than $15 S$. aureus cells were sufficient to cause infection in experimental lesions [14].

Microbes have an inherent ability to colonize any surface. Studies have shown that microbes can persist for weeks on stainless steel surfaces and polymeric materials used to fabricate touch surfaces in hospitals. The longer a nosocomial pathogen persists on a surface, the longer it may be a source for transmission to a susceptible patient or HCW [5].

\section{Methodology}

A cross-sectional study of indoor surfaces of paediatric wards at the university of Ilorin Teaching hospital was carried out to determine the pattern of bacterial contamination of surfaces according to material make of surfaces, last time of contact (with patient, patient relative and health care provider) and last time of cleaning and disinfection. Eight common surfaces (bed rails, bed lockers, radiant warmers, incubators, trolleys, medical tables, door handle and wash sinks) which patients, patients relative and healthcare provider often interact with within daily cleaning that were made from different materials (Aluminium, ceramic, plastic and wood) was sampled. 201 different surfaces made from four different materials distributed across the pediatrics wards of UITH were sampled for this study. Approval for research was obtained from the ethics and research committee of UITH with Reference Number: UITH/CAT/189/17 $/ 632$, before the commencement of the study.

Total population survey was used for the study, specimen were collected carefully by swabbing the surfaces of 86 bed rail, 69 bedside locker, 7 trolley, 6 medical table, 7 incubator, 6 radiant warmer, 17 wash sink and 3 door handles using a moistened sterile swab stick with $(0.9 \% \mathrm{w} / \mathrm{v})$ physiological saline and inserted into bijou bottle containing $5 \mathrm{ml}$ of sterile Stuart's transport medium and were transported with a minimal delay to Microbiology laboratory of UITH Ilorin for enumeration of microorganism.

Specimen were inoculated onto blood and MacConkey agar and were then incubated aerobically for $24 \mathrm{~h}$ at $37^{\circ} \mathrm{C}$ for the primary isolation of bacteria. Distinct colonies were further sub-cultured onto Nutrient agar plates and the $24 \mathrm{~h}$ old cultures were subjected to arrays of biochemical test for identification of the suspected organisms. The data obtained were analysed with Epi Info ${ }^{\mathrm{TM}} 7$.

\section{Results}

The pattern of contaminants according to the material make of sampled surfaces across the wards shows that $S$. aureus was the predominant contaminants on aluminium surfaces, $K$. pneumoniae and $A$. baumannii were found to be the major contaminant isolated from ceramic surfaces while $A$. baumannii was the predominant contaminant of wooden surfaces sampled as shown in Table 1.

\begin{tabular}{|l|l|l|l|l|}
\hline Growth Pattern & Aluminium & Ceramic & Plastic & Wood \\
\hline A. baumannii & 9 & 6 & 11 & 12 \\
\hline E. faecalis & 3 & 0 & 1 & 0 \\
\hline E. coli & 3 & 1 & 1 & 0 \\
\hline K. pneumoniae & 6 & 6 & 14 & 6 \\
\hline No Growth & 21 & 1 & 17 & 8 \\
\hline P. aeruginosa & 0 & 2 & 0 & 0 \\
\hline S. aureus & 26 & 5 & 27 & 5 \\
\hline S. epidermidis & 6 & 1 & 3 & 1 \\
\hline S. saprophyticus & 3 & 0 & 2 & 0 \\
\hline Total & 82 & 23 & 80 & 36 \\
\hline
\end{tabular}

Table 1: Growth Pattern According to Material Make (P-value $=0.0044$, $\left.\mathrm{X}^{2}=50.0914\right)$.

The aerobic bacteria contaminants pattern according to the last time of contact with patient's or healthcare workers, bed rails, bed lockers, radiant warmers and Incubators occupied by patient's was largely contaminated with 96 aerobic bacteria (60\%) of the total isolated aerobic bacterial contaminants while the non-occupied surfaces shows contamination with 36 (Total-No growth-ASB) aerobic bacterial contaminants $(22.5 \%)$ as shown in Table 2.

\begin{tabular}{|l|l|l|l|l|l|}
\hline Growth Pattern & $<\mathbf{2} \mathbf{h}$ & $\mathbf{3} \mathbf{3} \mathbf{~ m i n s}$ & $\mathbf{>} \mathbf{~ h}$ & Occupied & $\begin{array}{l}\text { Not } \\
\text { Occupied }\end{array}$ \\
\hline A. baumannii & 4 & 2 & 0 & $\mathbf{2 8}$ & 4 \\
\hline E. faecalis & 0 & 0 & 0 & 4 & 0 \\
\hline E. coli & 0 & 1 & 0 & 3 & 1 \\
\hline K. pneumoniae & 2 & 5 & 1 & 19 & 5 \\
\hline No Growth & 2 & 8 & 0 & 23 & 14 \\
\hline P. aeruginosa & 1 & 1 & 0 & 0 & 0 \\
\hline S. aureus & 4 & 5 & 1 & 32 & 21 \\
\hline S. epidermidis & 1 & 0 & 0 & 8 & 2 \\
\hline S. saprophyticus & 0 & 0 & 0 & 2 & 3 \\
\hline Total & 15 & 22 & 2 & 120 & 62 \\
\hline
\end{tabular}

Table 2: Growth Pattern According to Last Time of Contact (pvalue $=0.0043, \mathrm{X}^{2}=62.24$ ). 
Bacterial contamination pattern according to the time lapse of cleaning or disinfection time, surfaces that had been cleaned for greater $4 \mathrm{~h}$ prior to sample collection were found to have been contaminated with $86.3 \%$ of the isolates: 138 (Total-No growth and $\mathrm{ASB}=138$ ) aerobic bacteria were retrieved. Surfaces that were cleaned or disinfected less than $2 \mathrm{~h}$ prior to sample collection remained largely uncontaminated with only one [1] S. aureus as shown in Table 3.

\begin{tabular}{|l|l|l|l|}
\hline Growth Pattern & $<\mathbf{2} \mathbf{~}$ & $\mathbf{< 4} \mathbf{~}$ & $>\mathbf{4} \mathbf{~}$ \\
\hline A. baumannii & 0 & 6 & 32 \\
\hline E. faecalis & 0 & 1 & 3 \\
\hline E. coli & 0 & 2 & 3 \\
\hline K. pneumonia & 0 & 5 & 27 \\
\hline No Growth & 7 & 7 & 33 \\
\hline P. aeruginosa & 0 & 0 & 2 \\
\hline S. aureus & 1 & 13 & 49 \\
\hline S. epidermidis & 0 & 2 & 9 \\
\hline S. saprophyticus & 0 & 1 & 4 \\
\hline Total & 8 & 37 & 176 \\
\hline
\end{tabular}

Table 3: Growth Pattern According to Last Cleaning/Disinfection Time ( $\mathrm{p}$-value $=0.578, \mathrm{X}^{2}=28.2863$ ).

\section{Discussion}

The bacterial isolates from this study were retrieved from surfaces made from different material: aluminium, ceramic, plastic and wooden surfaces. It was suggested by Schmidt et al. [5] that copper surfaces reduces contamination within the wards. There was no copper surface among the sample sites of this study, all the aerobic bacterial isolates were retrieved from aluminium surfaces except $P$. aeruginosa, and this may be due to the dryness of all the aluminium surfaces sampled. However, $P$. aeruginosa was only retrieved from ceramic surfaces. It survives very well in moist environment, and this is similar to what was found in a study carried out in Mexico by Gracia-cruz et al. [15] where Pseudomonas species were predominantly found on the wash sinks. E. faecalis isolated from this study was isolated from aluminium and plastic surfaces is similar to the report of Neely and Maley [16] on the survival of Enterococci on plastic surfaces within hospital.

The association between the pattern of growth and material make of surfaces was presented in Table 1, and P-value was obtained as 0.0122 and $\mathrm{X}^{2}=53.914$ shows that there is statistical significance between the material make of surfaces and the pattern of growth.

The association between the pattern of growth and last time the surfaces were cleaned/disinfected shows that surfaces that were cleaned/disinfected less than $2 \mathrm{~h}$ prior sample collection were only contaminated with $S$. aureus as shown in Table 2. Those cleaned/ disinfected less than $4 \mathrm{~h}$ prior sample collection were contaminated with all the isolated aerobic bacteria except for $P$. aeruginosa and those cleaned/disinfected greater than $4 \mathrm{~h}$ before sample collection harbours all the isolated organisms. Samples taken from different surfaces following cleaning/disinfection showed that there was no statistically significant difference between the time lapse between cleaning/ disinfection and the pattern of growth (P-value of 0.4520 and $\left.\mathrm{X}^{2}=33.31\right)$ as shown in Table 3 .

An association between the pattern of growth and last time of contact with patients or healthcare workers shows a statistical significance and the P-value was obtained as 0.0032 and $\mathrm{X}^{2}=73.8295$. Those surfaces that were currently occupied by patients was largely contaminated with $60.0 \%$ of the isolated bacteria, while the nonoccupied surfaces shows contamination with $22.5 \%$ of the isolated bacteria as shown in Table 2. Surfaces may act as reservoirs of microbes which could in-turn leads to the spread of infection upon being touched by either healthcare workers, patient's relatives or patients.

\section{Conclusion}

Contamination of aluminium surfaces sampled from this study was mainly due to $S$. aureus, contamination of wooden surfaces was by $A$. baumannii and $P$. aeruginosa was only retrieved from ceramic surfaces. Surfaces became contaminated (specifically with $S$. aureus) within the first $2 \mathrm{~h}$ after cleaning/disinfection. However, the heaviest contamination occurred after greater than $4 \mathrm{~h}$ post cleaning/ disinfection. Contact time with non-critical hospital surfaces less than $30 \mathrm{~min}$ is associated with contamination and surfaces currently occupied by patients are mostly contaminated by microorganism. Enhanced cleaning, the use of no-touch methods for terminal room disinfection, and potentially the use of self-disinfecting surfaces may aid in reducing health care associated infections.

\section{Recommendations}

To the healthcare workers.

Wash your hands:

1. Before touching a patient.

2. Before clean/aseptic procedure.

3. After body fluid exposure risk.

4. After touching a patient.

5. After touching patients surrounding.

To patients and patient's relative.

Insist that healthcare worker to attending to you washes his/her hands (or at least uses a hand sanitizer) before contact with you.

Wash your hands after visiting a hospital ward.

Avoid the touching of surfaces within the wards.

To the Government and NGOs.

Government and NGOs should provide funds for research in form of grants for studies on hospital surfaces contamination and provide control measures to reduce the burden of healthcare associated infections.

\section{Limitation}

This study could not identify the source of the pathogenic aerobic bacterial contaminants on the selected indoor hospital surfaces and as well unable to incriminate the isolated bacteria to causing the infections among the paediatric population in the hospital. 
Citation: Saka KH, Akanbi II AA, Obasa TO, Raheem RA, Oshodi AJ (2017) Bacterial Contamination of Hospital Surfaces According to Material Make, Last Time of Contact and Last Time of Cleaning/Disinfection. J Bacteriol Parasitol 8: 312. doi:10.4172/2155-9597.1000312

Page 4 of 4

\section{References}

1. Mann EE, Manna D, Mettetal MR, May RM, Dannemiller EM, et al (2014) Surface Micropattern Limits Bacterial Contamination. Antimicrob Resist Infect Control 3: 28.

2. Otter JA, Yezli S, Salkeld JA, French GL (2013) Evidence that contaminated surfaces contribute to the transmission of hospital pathogens and an overview of strategies to address contaminated surfaces in hospital settings. Am J Infect Control 41: S6-S11.

3. Saka KH, Akanbi II AA, Obasa TO, Raheem RA, Oshodi AJ, et al. (2016) Pathogenic Aerobic Bacterial Contaminants on Non-Critical Hospital Surfaces within Paediatric Ward of a Nigerian Hospital. J Med Microb Diagn 5: 241.

4. Shiferaw T, Beyene G, Kassa T, Sewunet T (2013) Bacterial Contamination, Bacterial Profile and Antimicrobial Susceptibility Pattern of Isolates From Stethoscopes at Jimma University Specialized Hospital. Ann Clin Microbiol Antimicrob 12: 39.

5. Schmidt MG, Attaway HH, Sharpe PA, John J Jr, Sepkowitz KA, et al. (2012) Sustained Reduction of Microbial Burden on Common Hospital Surfaces through Introduction of Copper. J Clin Microbiol. 50: 2217-2223.

6. Boguz A, Stewart M, Hunter J, Yip B, Reid D, et al. (2013) How quickly do hospital surfaces become contaminated after detergent cleaning? Healthcare Inf 18: 3-9.

7. Boyce JM (2007) Environmental contamination makes an important contribution to hospital infection. J Hosp Infect 65: 50-54.

8. Weber DJ, Rutala WA, Miller MB, Huslage K, Sickbert-Bennett E (2010) Role of hospital surfaces in the transmission of emerging health care associated pathogens: Norovirus, Clostridium difficile, and Acinetobacter species. Am J Infect Control 38: S25-33.

9. Catano JC, Echeverri LM, Szela C (2012) Bacterial Contamination of Clothes and Environmental Items in a Third-Level Hospital in Colombia. Interdis Persp on Infect Dis.

10. Kramer A, Schwebke I, Kampf G (2006) How long do nosocomial pathogens persist on inanimate surfaces?A systematic review. BMC Infect Dis 6: 130 .

11. Weber DJ, Rutala WA (2013) Understanding and Preventing Transmission of Healthcare- Associated Pathogens Due to the Contaminated Hospital Environment Infect Control Hosp Epidemiol 34: 449-452.

12. Sehulster L, Chinn RY, CDC, HICPAC (2003) Guidelines for environmental infection control in health-care facilities: recommendations of CDC and the Healthcare Infection Control Practices Advisory Committee (HICPAC). MMWR Recomm Rep 52: 1-42.

13. McDonnell G, Burke P (2011) Disinfection: is it time to reconsider Spaulding? J Hosp Infect 78: 163-170.

14. Otter JA, Yezli S, French GL (2011) The Role Played by Contaminated Surfaces in the Transmission of Nosocomial Pathogens. Infect Control Hosp Epidemiol 32: 687-699.

15. Garcia-Cruz CP, Josefina M, Aguilar N, Arroyo-Helguera OE (2012) Fungal and Bacterial Contamination on Indoor Surfaces of a Hospital in Mexico. Jundishapur J of Microbiol 5: 460-464.

16. Neely AN, Maley MP (2000) Survival of Enterococci and Staphylococci on Hospital fabrics and plastic. J Clin Microbiol 38: 724-726. 